\title{
Microbiological vulnerability of eggs and environmental conditions in conventional and free-range housing systems
}

\section{Vulnerabilidade microbiológica de ovos e ambiente de produção no sistema convencional e de pastejo livre}

\author{
Julia Arantes Galvão ${ }^{*}$; Alexander Welker Biondo ${ }^{1}$; Fábio Sossai Possebon²; \\ Thiago Luiz Belém Spina²; Letícia Borges Nunes Correia ${ }^{2}$; \\ Caio Vaciloto Zuim²; João Bosco Pereira Guerra Filho²; \\ José Carlos Figueiredo Pantoja ${ }^{3}$; José Paes de Almeida Nogueira Pinto ${ }^{3}$
}

\begin{abstract}
Although Brazil is currently the world's eighth largest egg exporter, the shift of consumers towards free-range eggs may present new sanitary challenges. This study aims to evaluate the microbiological vulnerability of eggs and environmental conditions in a farm certified for both conventional and freerange systems using two standard methods (enterobacteria counting and Salmonella spp. survey). Two high-producing farms were selected for this study, one under both conventional and freerange systems at the same place as the test farm, and another under conventional system only as a control farm. Enterobacteriaceae counts were determined for eggshells; and detection of Salmonella spp. was conducted in eggs, nest box material, feeder, and sponge samples from water dispensers, feeders, production plant, besides water samples from nipple dispensers and artesian well. The average enterobacteria count $\left(\log \mathrm{CFUmL}^{-1}\right)$ was 0.09 for conventional and 1.73 for free-range systems $(\mathrm{p}<$ 0.001). While Salmonella spp. was not detected in the conventional system but was present in one feeder and three eggshells from the free-range system. Therefore, the conventional system demonstrated better hygiene-sanitary status than the free-range one. Moreover, controlling food safety should always be considered when improving animal welfare.
\end{abstract}

Key words: Enterobacteria. Food safety. Microbial contamination. Public health. Salmonella spp.

\section{Resumo}

\begin{abstract}
Apesar do Brasil ser considerado o oitavo maior exportador mundial de ovos, mudanças nas preferências dos consumidores relacionadas a ovos produzidos em sistemas de pastejo livre, podem representar novos desafios sanitários. Neste estudo o objetivo foi avaliar a vulnerabilidade microbiológica dos ovos e ambiente de produção numa fazenda certificada para sistema convencional e de pastejo livre, utilizando dois métodos considerados padrão (contagem de Enterobactérias e pesquisa de Salmonella). Duas fazendas de alta produção de ovos foram selecionadas para o estudo, sendo que uma delas continha o sistema convencional e também o sistema de pastejo livre de criação na mesma localidade. A segunda fazenda (sistema convencional) foi utilizada como controle. A enumeração de enterobactérias
\end{abstract}

\footnotetext{
${ }^{1}$ Profs., Departamento de Medicina Veterinária, Setor de Ciências Agrárias, Universidade Federal do Paraná, UFPR, Curitiba, Brasil.E-mail: juliaarantesgalvao@gmail.com; abiondo@ufpr.br

${ }^{2}$ Médicos Veterinários, Discentes, Curso de Doutorado do Programa de Pós-Graduação em Medicina Veterinária, Faculdade de Medicina Veterinária e Zootecnia, Univ. Estadual Paulista - UNESP, Botucatu, Brasil. E-mail: fabio.cid@fmvz.unesp.br; thiagospina@uol.com.br; leticiaborgesnc@gmail.com; cacozuin@hotmail.com; joaoboscovet@hotmail.com

${ }_{3}^{3}$ Profs., Programa de Pós-Graduação em Medicina Veterinária. Faculdade de Medicina Veterinária e Zootecnia, Univ. Estadual Paulista - UNESP, Botucatu, Brasil. E-mail: pantoja@fmvz.unesp.br; josepaes@fmvz.unesp.br

* Author for correspondence
} 
foi realizada nas cascas dos ovos e a pesquisa de Salmonella nas cascas dos ovos, no material de ninho, nos comedouros, bebedouros, ração (comedouros e fábrica) e água (bebedouros e poço artesiano). A contagem média de enterobactérias $\left(\log \mathrm{UFCml}^{-1}\right)$ foi 0,09 para sistema convencional e 1,73 para sistema de pastejo livre $(\mathrm{p}<0,001)$. Salmonella não foi detectada no sistema convencional, mas estava presente em comedouro e em três cascas de ovos do sistema de pastejo livre. Dessa forma, o sistema convencional apresentou melhor condição higiênico-sanitária que o sistema de pastejo livre. Além disso, controlar a segurança de alimentos é imperativo quando é melhorada a condição de bem-estar.

Palavras-chave: Enterobacteriaceae. Contaminação bacteriana. Salmonella. Saúde pública. Segurança de alimentos.

\section{Introduction}

Conventional systems (battery cages) lead commercial egg production worldwide due to their reportedly efficient disease prevention processes (WHILEY; ROSS, 2015). However, shifts in egg consumption have drawn attention to potential animal welfare issues and generated demand for alternative laying systems with improved hen wellbeing. In this way, free-range systems could be an ideal choice for egg production and hen welfare (JONES at al., 2012); however, despite fulfilling consumer wishes, its microbiological implications are still controversial (DE REU et al., 2005; SINGH et al., 2009; JONES et al., 2011).

Microbiologically contradictory findings have been found between conventional and free-range systems since they have diverse farm systems and variables, e.g. bird strain, diet, age, housing system, aging, climate, and management practices (HOLT et al., 2011). In salmonellosis outbreaks in the United States, $75 \%$ of the cases stem from egg-based products or had egg as an ingredient (BRADEN, 2006); therefore, egg safety should always be carefully considered when comparing laying systems.

Egg safety is paramount importance to poultry related diseases in general. Recently, the European Union has reported a gradual decrease in infected flocks, in parallel to a fall in human salmonellosis cases (EUROPEANFOOD SAFETYAUTHORITY, 2011). Likewise, cases of egg-transmitted diseases, related to Salmonella spp., have also decreased in about 10-fold in both Japan (MINISTRY OF
HEALTH, LABOUR AND WELFARE OF JAPAN, 2011; ESAKI et al., 2013) and Brazil (BRASIL, 2013) over the past decade. Unsurprisingly, European regulations for salmonellosis control have been reliably implemented (EC, 2003; EC, 2006) and mandatory vaccinations (EUROPEAN FOOD SAFETY AUTHORITY, 2007; COLLARD et al., 2008) have reduced the disease (BARROW et al., 2012).

Although the Brazilian Government has certified both conventional and free-range egg systems, both of which undergo periodic sanitary and microbiological inspections, contaminations in these systems have not been fully compared. Accordingly, this study aims to evaluate the microbiological vulnerability of eggs and environmental conditions at a farm certified for both conventional and free-range systems, using two standard methods (enterobacteria counting and Salmonella spp. survey).

\section{Material and Methods}

\section{Farms}

Two high-production egg farms certified by the Brazilian Inspection Service were selected for this study. One of them with both conventional and free-range laying systems was used as a test farm and the other with conventional only as a control. Both farms were located in Western São Paulo State (22 $\left.2^{\circ} 43^{\prime} 52^{\prime \prime} \mathrm{S} 48^{\circ} 34^{\prime} 14^{\prime \prime} \mathrm{W}\right)$, which is the largest egg producer in Brazil and currently responsible for $29.5 \%$ of national egg production (BRASIL, 2016). 
All hens at both farms received the standard vaccines recommended for the area, including against Avian Infectious bronchitis (H120), Newcastle disease (La Sota and HB1), Marek's disease (Rispens + HVT), Infectious Bursal Disease Gumboro, Avian pneumoviruses (APV), mycoplasmosis, and Infectious coryza. Free-range hens also received additional vaccines against salmonellosis and egg dropping syndrome (EDS). Ad-lib water from an on-farm artesian well was automatically provided to all laying hens in both farms via nipple dispensers. Eggs were manually collected twice daily, cleaned with warm-water, and packed at the farm, and then delivered to the market for sale.

The test farm included same-orientation facilities with conventional (250,000 hens averaging 38,000 eggs daily) and free-range (45,000 hens averaging 13,500 eggs daily) systems, both using a 12-h natural and 4-h artificial light schedule. One-day age commercial birds (Hysex Brown strain) were acquired, being housed in $45 \times 60 \mathrm{~cm}$ cages for the conventional system and in a $2 \mathrm{~m}^{2} /$ bird living area for the free-range one; these areas had nest boxes, roosts, rice straw bedding, and an outside pasture area. The birds were beak-trimmed on day-7 and week-9. On-farm prepared feed was provided ad-lib using wooden troughs in the conventional system and plate-type feeders in the free-range. The fact of having both systems within the same farm minimized food and environmental biases.

The control was a nearby (20 miles) farm under a conventional laying system, using the same housing system and federal inspection. The only difference between farms was regarding the commercial source (Novogen strain), with a total number of laying hens of 350,000 and overall average production of 46,000 eggs/day.

The veterinarian was interviewed about prevention and control measures for Salmonella spp. in the studied flocks. Considering the answers, only the free-range chickens had been already vaccinated for Salmonella spp., and none of them received antibiotics therapy against the bacterium before or during the experiment period.

\section{Sampling}

Batches of approximately 5,000 birds were randomly selected from each system on the $28^{\text {th }}$ day of production peak. Firstly, simulations were performed using commercially available statistical software (SAS INSTITUTE, 2009); thus, the minimum number of eggs required for statistically significant results for both enterobacteria count (MACDIARMID, 1988; DOHOO et al., 2010) and Salmonella spp. detection (DOHOO et al., 2010) could be estimated.

The differences in enterobacteria counts (log $\mathrm{CFUmL}^{-1}$ ) between conventional and free-range systems were determined as previously described (RODENBURG et al., 2008; DE REU et al., 2009), being estimated in 0.3-0.9 log CFU eggshell ${ }^{-1}$ (1.01.2 with standard deviation). Simulations were performed using a statistical power of $80 \%$ with an $\alpha$ value of 0.05 (two-tailed test). Simulation results pointed to a minimum of 63 samples within four samplings per system for enterobacteria counting, totaling 756 eggs. Yet for Salmonella spp., in a total of 5,000 eggs, assuming 2-4\% egg contamination (POPPE et al., 1998; DE BOER; WIT, 2000) and $90 \%$ washed eggshell sensitivity to microbiological examination, we estimated a minimum sample of 200 eggs per system, within a total of 400 eggs.

In farm 1, birds were randomly selected from each system on the $28^{\text {th }}$ day of production peak for the first collection on $31 / 08$, the second on $14 / 09$ ( $42^{\text {nd }}$ day of production), the third on $21 / 09\left(49^{\text {th }}\right.$ day of production), and the last one on $27 / 08$ ( $55^{\text {th }}$ day of production). In farm 2 , the first collection occurred on $22 / 10$ ( $28^{\text {th }}$ day of production peak), being then performed weekly until $12 / 11$. These dates were chosen according to the laboratory availability for sample processing, along with the peak production of hens. On each sampling day, we collected eggs (as provided in simulation results), 100-g nest box 
material (rice straw), sponge samples from feeders water dispensers, 100-g feed samples from feeders and feedmill, and 100-mL water samples from nipple dispensers and artesian well, all of them from both systems. Prior to sampling, sponges were soaked in a $10-\mathrm{mL} 0.85 \%$ saline solution and stored in collection bags containing $90 \mathrm{~mL}$ of this solution.

In samplings 1 and 2, 100 eggs were manually collected (using gloves) directly from conveyor belts in the conventional system and from nest boxes in the free-range. These eggs were individually placed into sterile bags for Salmonella spp. testing, among which 63 were used for enterobacteria counts. In samplings 3 and 4, 63 eggs were collected only for enterobacteria counts. All these samples were immediately taken to the laboratory in a thermally cooled box. The analyses started within $2 \mathrm{~h}$ for enterobacteria counts and $24 \mathrm{~h}$ for Salmonella spp. tests.

\section{Determination of bacterial eggshell contamination}

Initially, enterobacteria counts were determined for each egg by immersing it into a $10-\mathrm{mL}$ buffered peptone water $(1 \%)$ and rinsed twice in a plastic bag for 1 min within a 5-min interval between rinses (DE REU et al., 2005). Thereafter, serial dilutions of the resultant solution were prepared, transferring a 1-mL aliquot of each to commercial plates (Petrifilm ${ }^{\mathrm{TM}}$ EB 6421, 3M ${ }^{\mathrm{TM}}$ Company, Sao Paulo, Brazil), according to the manufacturer's instructions. The enterobacteria counts were then converted to a logarithmic scale (log 10), with averages compared by analysis of variance (SAS INSTITUTE, 2009).

Then, Salmonella spp. testing was performed using the remaining rinse solution after incubating it at $35-37^{\circ} \mathrm{C}$ for $24 \mathrm{~h}$. All aliquots $(25 \mathrm{~g}$ feed, $25 \mathrm{~g}$ nest box material, $25 \mathrm{~mL}$ water and $25 \mathrm{~mL}$ sponge solution) were placed into plastic bags containing $225-\mathrm{mL}$ buffered peptone water (1\%), being then incubated at $35-37^{\circ} \mathrm{C}$ for $24 \mathrm{~h}$, with all subsequent steps performed as previously described (ANDREWS et al., 2011). After, the obtained strain cultures were sent to the National Reference Laboratory for Enterobacteria (Fundação Oswaldo Cruz, São Paulo, Brazil) for serotype identification. A Fisher test was used to compare the proportion of eggs testing positive for Salmonella spp. between conventional and free-range systems (SAS INSTITUTE, 2009).

This study was approved by the Ethics Committee for Animal Experimentation of the Univ. Estadual Paulista - UNESP (under protocol number 176/2012).

\section{Results}

When comparing all eggshell samples, enterobacteria counts from the conventional system were lower than those from the free-range one ( $p$ $<0.001$ ) (Figure 1). Overall, nine samples were discarded due to egg breakage during transport. In control farm, 117 out of 200 tested egg samples $(58.5 \%)$ showed $<1 \log \mathrm{CFU}$ eggshell ${ }^{-1}$ for enterobacteria, while the remaining samples (41.5\%) yielded between 1.0 and $1.7 \log$ CFU eggshell ${ }^{-1}$. The highest enterobacteria counts were observed for the free-range system at samples 2 and 3 (Figure 2), ranging from 0.71 to $1.32 \log \mathrm{CFU}$ eggshell ${ }^{-1}$.

Salmonella spp. was not detected in the conventional system either in test or control farms for eggshell, environment, feed or water samples. Conversely, in the free-range system, 3 out of 194 (1.5\%) eggs and 1 out of $13(7.7 \%)$ feeders were contaminated with Salmonella spp. (Table 1). Unfortunately, 3 out of $4(75.0 \%)$ of the resultant cultures died, and the remaining samples (from feeders) were identified as Salmonella serovar Senftenberg. 
Figure 1. Association between housing system and bacterial contamination in eggshells and in the egg-production environment.

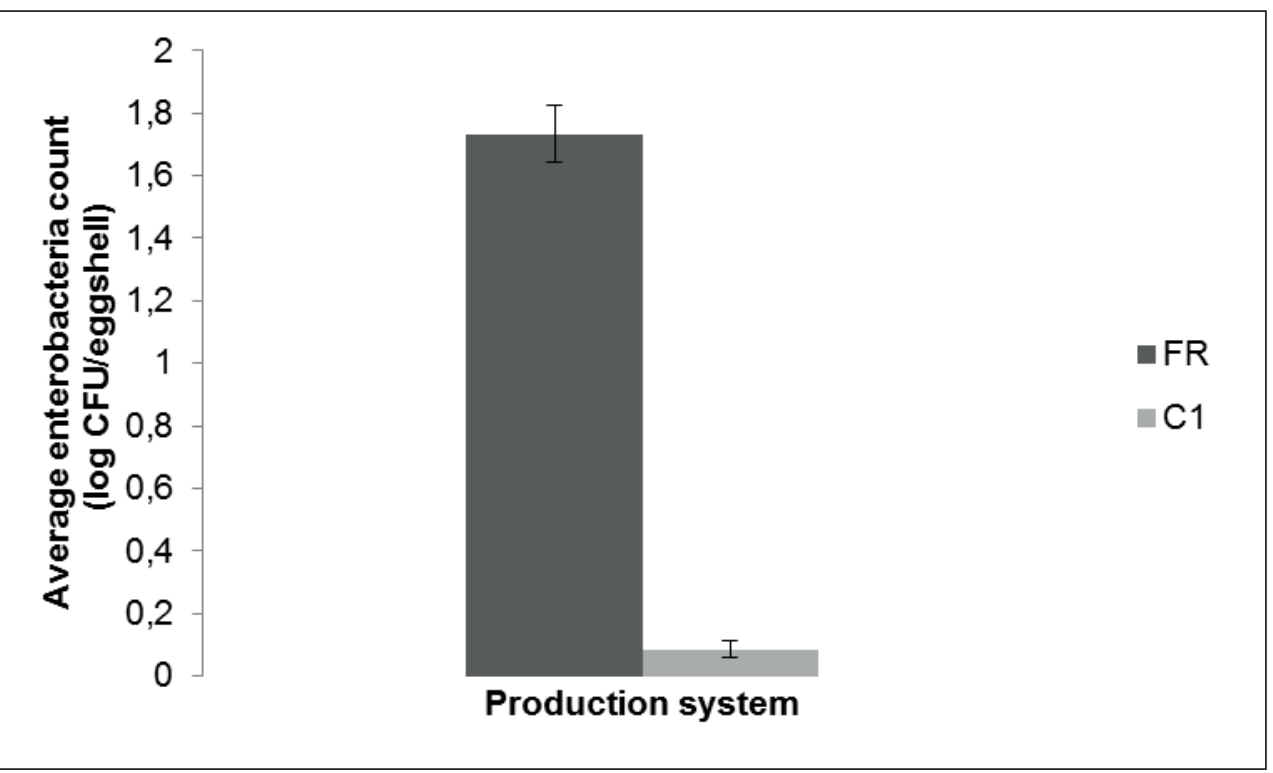

Figure 2. Enterobacteria counts in eggs of FR and $\mathrm{C} 1$ systems according to the sample set $(p=0.005$ for interaction between system and sample set).

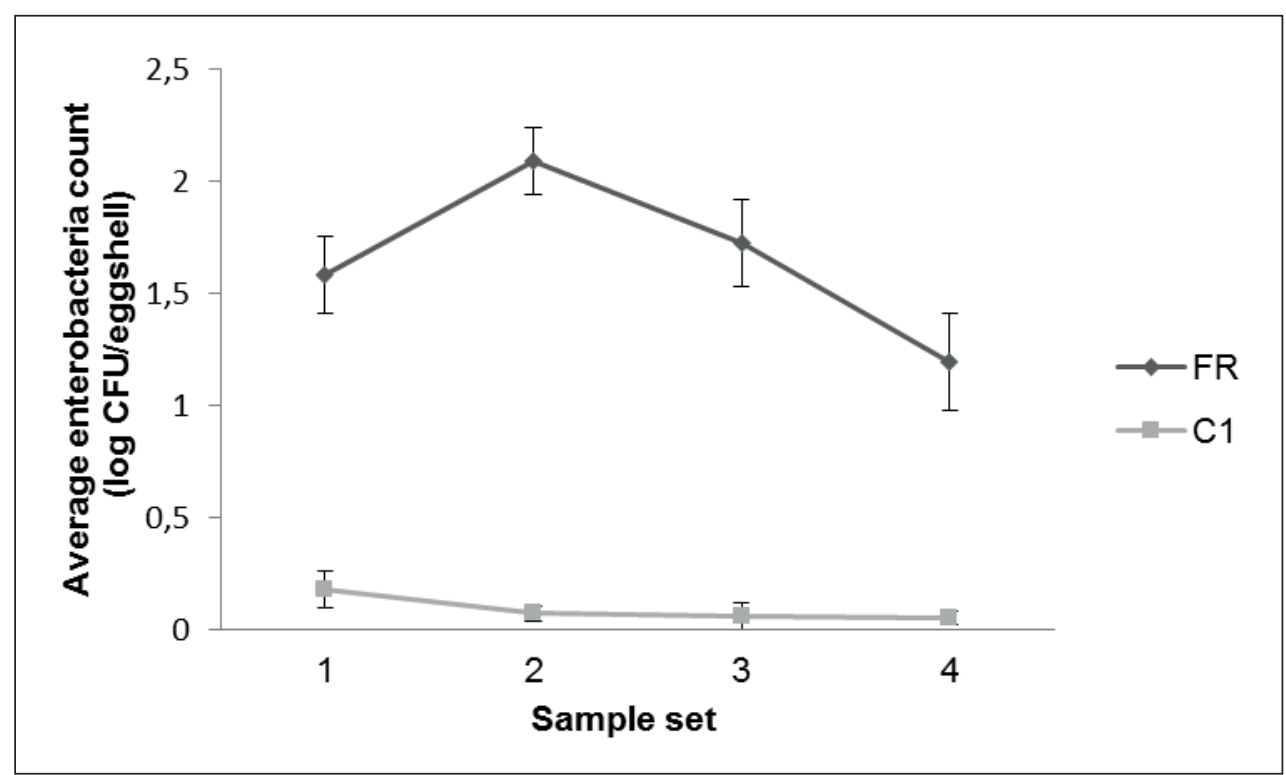


Table 1. Association between housing systems and bacterial contamination in eggshells and in the egg-production environment.

\begin{tabular}{cccccc}
\hline $\begin{array}{c}\text { Salmonella } \\
\text { spp. }\end{array}$ & $\begin{array}{c}\text { Number of } \\
\text { observations }\end{array}$ & $\begin{array}{c}\text { Average } \\
\text { Enterobacteriaceae } \\
\text { Count } \\
\left(\log \text { CFU } \mathbf{~ m L}^{-1}\right)\end{array}$ & $\begin{array}{c}\text { Standard } \\
\text { Error }\end{array}$ & $\begin{array}{c}\text { Minimum } \\
\text { Enterobacteriaceae } \\
\text { Count } \\
\left(\log \mathbf{C F U} \mathbf{~ m L}^{-1}\right)\end{array}$ & $\begin{array}{c}\text { Maximum } \\
\text { Enterobacteriaceae } \\
\text { Count } \\
\left(\log \mathbf{C F U} \mathbf{~ m L}^{-1}\right)\end{array}$ \\
\hline Presence & 3 & 3.40 & 0.65 & 2.74 & 4.03 \\
Absence & 389 & 1.40 & 0.05 & $<1$ & 4.16 \\
\hline
\end{tabular}

\section{Discussion}

The present findings differ from a previous study (DE REU et al., 2005), which yielded similar Gramnegative bacteria results for eggs left in the nest boxes both for free-range (3.4 log CFU eggshell ${ }^{-1}$ ) and for the conventional system (3.5 log CFU eggshell $\left.{ }^{-1}\right)$. Although our findings are similar to those of Moyle et al. (2016), with enterobacteria counts ranging from 0.68 to $0.98 \log \mathrm{CFU}$ eggshell ${ }^{-1}$ in two evaluated flocks. When comparing free-range and battery cage systems in Australia, Parisi et al. (2015) observed that mean counts of Enterobacteriaceae in free-range egg shells were about $1 \log \mathrm{CFU} / \mathrm{mL}$ higher ( $90 \%$ greater) than in battery cage eggshells. These authors observed counts ranging from 3.6 to $5.4 \log 10 \mathrm{CFU} / \mathrm{mL}$ rinsate for free-range and 2.1 to $3.6-\log 10 \mathrm{CFU} / \mathrm{mL}$ rinsate for battery cages. However, compared to our results, this study in Australia had greater results.

The highest enterobacteria counts were achieved in the free-range system at samplings 2 and 3, which might have occurred due to rainfall events during the pre-established sampling. In addition, one of the water dispensers was leaking, which perhaps might have facilitated microbiological propagation. Such outcomes negatively influence the sampleto-sample standard deviation, and would probably never occur using a conventional system. Since the hens came from the same source, this study clearly shows that the free-range housing itself can generate a microbiological risk. As such, egg safety is an increasing concern for the Brazilian National Program for Pathogen Control and other countries, particularly for Salmonella spp. (EUROPEAN FOOD SAFETY AUTHORITY, 2011). Pathogen detection and control in eggshells and in the rearing environment remain a worldwide challenge in freerange systems.

Similarly to our results, among 212 eggs evaluated from both free-range and battery-cage systems in Australia, five of them belonging to the free-range system were positive for Salmonella spp. (PARISI et al., 2015). Conversely, Jones et al. (2012) observed no differences or lower numbers of Salmonella-positive egg samples in free-range systems.

Both plate type and hen housing conditions (free roaming, roost sitting, and feeder defecation) may have caused feeder contamination by Salmonella spp. (along with eggshells); therefore, these facilities should be constantly cleaned and monitored. Salmonella spp. was not found in the nipple water dispensers, probably due to its environmentally preventive one-direction format. It is important to state that the probability of an eggshell being Salmonella spp. positive is higher when environmental samples are positive for the bacteria (GOLE et al., 2014).

The serovar detected in the feeders, Salmonella Senftenberg, has been isolated from raw food, foodprocessing plants, environment, feedmills, and poultry farms, which may be a persistent source of contamination (BOUMART et al., 2012; SANAD et al., 2016). This serovar is associated with foodborne outbreaks in humans (RUSHDY, 1998; MOHLEBOETANI, 2001), and its environmental persistence 
may be linked to stress resistance such as low $\mathrm{pH}$, heating, drying, and irradiation (MACKEY; DERRICK, 1982).

A hybrid system such as enriched cages could be an intermediate solution providing a sanitary control similar to the conventional model. Although this system does not provide outdoor access, the hens are free to walk around $\left(750 \mathrm{~cm}^{2} /\right.$ bird $)$, sit on roosts, nest box and bedding access, besides having nail-scratching areas with a broad space for feeders. This system is still deficient because hen foraging and dust bathing are limited or impossible, and hen injuries may occur during the housing due to the lack of beak trimming. Nevertheless, such a hybrid system could provide an intermediate option to a free-range system (HOLT et al., 2011; JONES et al., 2011), and further studies should be conducted to fully establish its microbiological safety. Another alternative for preventing diseases caused by eggs produced via free-range system would be the pasteurization of commercial products. But even if such a process may exterminate important pathogens such as Salmonella spp., the concern about pasteurized food and the rising demand for unprocessed fresh whole food by consumers are still a challenge to be overcome (WHILEY; ROSS, 2015).

This study serves as a warning to egg producers since "ethical" systems (such as free range) have focused on animal welfare (HOLT et al., 2011; WHILEY; ROSS, 2015), but little attention has been paid to microbiological safety and general public health.

\section{Conclusion}

In summary, once enterobacteria counts and Salmonella spp. detection were statistically superior in the free-range system, this study indicates that such system is more vulnerable microbiologically when compared to a conventional system.

\section{References}

ANDREWS, W. H.; JACOBSON, A.; HAMMACK, T. Salmonella. Bacterial analytical manual [on-line]. Silver Spring: Food and Drug Administration, 2011. Chapter 5. Available at: <http://www.fda.gov/Food/ FoodScienceResearch/LaboratoryMethods/ucm070149. htm> Accessed at: 10 may. 2012.

BARROW, P. A.; JONES, M. A.; SMITH, A. L.; WIGLEY, P. The long view: Salmonella the last forty years. Avian Pathology, London, v. 41, n. 5, p. 413-420, 2012.

BOUMART, Z.; ROCHE, S. M.; LALANDE, F.; VIRLOGEUX-PAYANT, I.; HENNEQUET-ANTIER, C.; MENANTEAU, P.; GABRIEL, I.; WEILL, F. X.; VELGE, P.; CHEMALY, M. Heterogeneity of persistence of Salmonella enterica serotype Senftenberg strains could explain the emergence of this serotype in poultry flocks. PLoS One, San Francisco, v. 7, n. 4, p. 1-10, 2012.

BRADEN, C. R. Salmonella enterica serotype Enteritidis and eggs: a national epidemic in the United States. Clinical Infectious Diseases, Chicago, v. 43, n. 4, p. 512517, 2006.

BRASIL. Instituto Brasileiro de Geografia e Estatística. Indicadores. Estatística da Produção Pecuária. Ranking e variação anual da produção de ovos de galinha Unidades da Federação - Terceiro trimestre de 2016. Brasília: IBGE, 2016. Disponível em: <ftp://ftp.ibge. gov.br/Producao_Pecuaria/Fasciculo_Indicadores IBGE/ abate-leite-couro-ovos_201603caderno.pdf>. Acesso em: 16 abr. 2017.

. Ministério da Saúde. Secretaria de Vigilância em Saúde - SVS Departamento de Vigilância das Doenças Transmissíveis. Coordenação Geral de Doenças Transmissíveis. Unidade de Vigilância das Doenças de Transmissão Hídrica e Alimentar. Doenças Transmitidas por alimentos. Brasília: Ministério da Saúde, 2013. Disponível em: $<\mathrm{http}: / /$ www.saude.gov.br $>$. Acesso em: 19 set. 2013.

COLLARD, J. M.; BERTRAND, S.; DIERICK, K.; GODARD, C.; WILDEMAUWE, C.; VERMEERSCH, K.; DUCULOT, J.; VAN IMMERSEEL, F.; PASMANS, F.; IMBERECHTS, H.; QUINET, C. Drastic decrease of Salmonella Enteritidis isolated from humans in Belgium in 2005, shift in phage types and influence on food-borne outbreaks. Epidemiology and Infection, Cambridge, v. 136, n. 6, p. 771-781, 2008. 
. European Community. Commission Regulation (EC) No 1168/2006 of 31 July 2006 implementing regulation (EC) no 2160/2003 as regards a community target for the reduction of the prevalence of certain Salmonella serotypes in laying hens of Gallus gallus and amending Regulation (EC) no 1003/2005. Official Journal of the European Union. L211, v. 49, p. 4-9, 2006.

European Community. Commission Regulation (EC) no 2160/2003 of the European Parliament and of the Council of November 17, 2003 on the control of Salmonella and other specified foodborne zoonotic agents. Official Journal of the European Union L325, v. 41, p. 1-15, 2003.

DE BOER, E.; WIT, B. Salmonella in eieren. Tijdschrift Voor Diergeneeskunde, Amsterdam, v. 124, n. 4, p. 126127, 2000.

DE REU, K.; GRIJSPEERDT, K.; HEYNDRICKX, M.; UYTTENDAELE, M.; HERMAN, L. The use of total aerobic and Gram-negative flora for quality assurance in the production chain of consumption eggs. Food Control, Kidlington, v. 16, n. 2, p. 147-155, 2005.

DE REU, K.; RODENBURG, T. B.; GRIJSPEERDT, K.; MESSENS, W.; HEYNDRICKX, M.; TUYTTENS, F. A.; SONCK, B.; ZOONS, J.; HERMAN, L. Bacteriological contamination, dirt, and cracks of eggshells in furnished cages and noncage systems for laying hens: an international on-farm comparison. Poultry Science, Oxford, v. 88, n. 11, p. 2442-2448, 2009.

DOHOO, I.; MARTIN, W.; STRYHN, H. Veterinary epidemiologic research. $2^{\text {th }}$ ed. Prince Edward Island: Atlantic Veterinary College Inc., University of Prince Edward Island, 2010. 865 p.

ESAKI, H.; SHIMURA, K.; YAMAZAKI, Y.; EGUCHI, M.; NAKAMURA, M. Salmonella prevalence in eggs in Japan. Epidemiology and Infection, Cambridge, v. 141, n. 5, p. 941-943, 2013.

EUROPEAN FOOD SAFETY AUTHORITY - EFSA. Report of the task force on zoonoses data collection on the analysis of the baseline study on the prevalence of Salmonella in holdings of laying hen flocks of Gallus gallus. Parma: European Food Safety Authority Journal, v. $97,2007.84$ p.

The European Union summary report on trends and sources of zoonoses, zoonotic agents, and foodborne outbreaks in 2009. Parma: European Food Safety Authority Journal, European Food Safety Authority Journal, 2011. v. 9, n. 3, 378 p.

GOLE, V. C.; TOROK, V.; SEXTON, M.; CARAGUEL, C. G.; CHOUSALKAR, K. K. Association between indoor environmental contamination by Salmonella enterica and contamination of eggs on layer farms. Journal of Clinical Microbiology, Washington, v. 52, n. 9, p. 3250-3258, 2014.

HOLT, P. S.; DAVIES, R. H.; DEWULF, J.; GAST, R. K.; HUWE, J. K.; JONES, D. R.; WALTMAN, D.; WILLIAN, K. R. The impact of different housing systems on egg safety and quality. Poultry Science, Oxford, v. 90, n. 1, p. 251-262, 2011.

JONES, D. R.; ANDERSON, K. E.; GUARD, J. Y. Prevalence of coliforms, Salmonella, Listeria and Campylobacter associated with eggs and the environment of conventional cage and free-range egg production. Poultry Science, Oxford, v. 91, n. 5, p. 1195-1202, 2012.

JONES, D. R.; ANDERSON, K. E.; MUSGROVE, M. T. Comparison of environmental and egg microbiology associated with conventional and free-range laying hen management. Poultry Science, Oxford, v. 90, n. 9, p. 2063-2068, 2011.

MACDIARMID, S. C. Future options for brucellosis surveillance in beef herds. New Zealand Veterinary Journal, Wellington, v. 36, n. 1, p. 39-42, 1988.

MACKEY, B. M.; DERRICK, C. M. The effect of sub lethal injury by heating, freezing, drying and gammaradiation on the duration of the lag phase of Salmonella Typhimurium. Journal of Applied Microbiology, Oxford, v. 53, n. 2, p. 243-251, 1982.

MINISTRY OF HEALTH, LABOUR AND WELFARE OF JAPAN. Food poisoning investigation reports. Tóquio: Ministry of Health, Labour and Welfare of Japan, 2011. Available at: <http://www.mhlw.go.jp/ english/topics/foodsafety/poisoning/dl/Food_Poisoning Statistics_2009.pdf $>$ Accessed at: 5 oct. 2011.

MOHLE-BOETANI, J. C.; FARRAR, J. A.; WERNER, S. B.; MINASSIAN, D.; BRYANT, R.; ABBOTT, S.; SLUTSKER, L.; VUGIA, D. J. Escherichia coli O157 and Salmonella infections associated with sprouts in California, 1996-1998. Annals of Internal Medicine, Philadelphia, v. 135, n. 4, p. 239-247, 2001.

MOYLE, T.; DRAKE, K.; GOLE, V.; CHOUSALKAR, K.; HAZEL, S. Bacterial contamination of eggs and behaviour of poultry flocks in the free range environment. Comparative Immunology, Microbiology and Infectious Diseases, Exeter, v. 49, p. 88-94, 2016.

PARISI, M. A.; NORTHCUTT, J. K.; SMITH, D. P.; STEINBERG, E. L.; DAWSON, P. L. Microbiological contamination of shell eggs produced in conventional and free-range housing systems. Food Control, Kidlington, v. 47, n.1, p. 161-165, 2015. 
POPPE, C.; DUNCAN, C.; MAZZOCCO, A. Salmonella contamination of hatching and table eggs: a comparison. Canadian Journal of Veterinary Research, Ottawa, v. 62, n. 3, p. 191-198, 1998.

RODENBURG, B.; TUYTTENS, F.; DE REU, K.; HERMAN, L.; ZOONS, J.; SONCK, B. Welfare assessment of laying hens in furnished cages and noncage systems: an on-farm comparison. Animal Welfare, Hertfordshire, South Mimms, v. 17, n. 4, p. 363-373, 2008.

RUSHDY, A. A.; STUART, J. M.; WARD, L. R.; BRUCE, J.; THRELFALL, E. J.; PUNIA, P.; BAILEY, J. R. National outbreak of Salmonella Senftenberg associated with infant food. Epidemiology \& Infection, Cambridge, v. 120, n. 2, p. 125-128, 1998.
SANAD, Y. M.; JOHNSON, K.; PARK, S. H.; HAN, J.; DECK, J.; FOLEY, S. L.; KENNEY, B.; RICKE, S.; NAYAK, R. Molecular characterization of Salmonella enterica Serovars isolated from a Turkey production facility in the absence of selective antimicrobial pressure. Foodborne Pathogens and Disease, Larchmont, v. 13, n. 2, p. 80-87, 2016.

SINGH, R.; CHENG, K. M.; SILVERSIDES, F. G. Production performance and egg quality of four strains of laying hens kept in conventional cages and floor pens. Poultry Science, Oxford, v. 88, n. 2, p. 256-264, 2009.

STATISTICAL ANALYSIS SYSTEM INSTITUTE SAS Institute INC. SAS Campus Drive. Cary: North Carolina, 2009.

WHILEY, H.; ROSS, K. Salmonella and eggs: from production to plate. International Journal of Environmental Research and Public Health, Basel, v. 12, n. 3, p. 2543-2556, 2015. 
